\title{
I CAN SEE CLEARLY NOW: VIDEOCONFERENCE HEARINGS \\ AND THE LEGAL LIMIT ON HOW TRIBUNALS ALLOCATE RESOURCES
}

\section{Lorne Sossin* \& Zimra Yetnikoff*}

Videoconferencing has generated ambivalence in the legal community. Some have heralded its promise of unprecedented access to justice, especially for geographically remote communities. Others, however, have questioned whether videoconferencing undermines fairness. The authors explore the implications of videoconferencing through the case study of the Ontario Landlord and Tenant Tribunal, which is one of the busiest adjudicative bodies in Canada. This analysis highlights concerns both with videoconferencing in principle and in practice. While such concerns traditionally have been the province of public administration, the authors argue that a tribunal's allocation of resources and the sufficiency of its budget are also core concerns of administrative law. Administrative law reaches beyond conventional doctrines of procedural fairness on the one hand and substantive rationality on the other. How the legislature structures and funds decision-making bodies is not just a matter of political preference but also of legal sufficiency. The common law, the Charter of Rights, and unwritten constitutional principles such as the rule of law and access to justice all provide potential constraints both on governments and tribunals as to the organization and conduct of adjudicative hearings, especially in settings like the Landlord and Tenant Tribunal, where the rights of vulnerable people are at stake. While a challenge to the videoconferencing practices of the Landlord and Tenant Tribunal has yet to be brought, the authors conclude that eventually the intersection of tribunal resources with the fairness and reasonableness of that tribunal's decision-making will reach the courts. How the courts resolve these challenges may represent the next frontier of administrative law.

La vidéoconférence a suscité de l'ambivalence au sein de la communauté juridique. Certains ont proclamé sa promesse d'un accès sans précédent à la justice, surtout pour les communautés géographiquement éloignées. D'autres, cependant, ont soulevé la question à savoir si la vidéoconférence mine l'équité. Les auteurs explorent les conséquences de l'utilisation de la vidéoconférence en faisant une étude de cas du Tribunal du logement de l'Ontario, un des organismes juridictionnels les plus occupés au Canada. Cette analyse met en lumière des préoccupations en rapport avec la vidéoconférence en principe et en pratique. Quoique de telles préoccupations ont traditionnellement été

* Faculty of Law, University of Toronto. We wish to thank Julia McNally, Kathy Laird and the staff of The Advocacy Centre for Tenants Ontario [ACTO] for their helpful contributions to this research project (although the responsibility for the material and arguments presented in this paper is our own). We also wish to acknowledge the generous support of the Social Sciences and Humanities Research Council of Canada and the Faculty of Law at the University of Toronto. We are grateful for the comments and suggestions from the anonymous reviewers and the editors of the Yearbook. Finally we benefited from the superb research assistance of Allison Speigel in the latter stages of this project.

** Crown Counsel, Ministry of the Attorney General - Special Investigations Unit. 
du ressort de l'administration publique, les auteurs soutiennent que l'allocation des ressources par un tribunal et la suffisance de son budget sont également des préoccupations centrales $d u$ droit administratif. Le droit administratif va au delà des doctrines conventionnelles d'équité procédurale d'une part et de la rationalité substantive d'autre part. La façon dont le législateur organise et finance les organismes décideurs n'est pas simplement question de préférence politique mais aussi de suffisance légale. Le common law, la Charte des droits et les principes constitutionnels non écrits tels que l'autorité de la loi et l'accès à la justice imposent tous des contraintes potentielles aux gouvernements et aux tribunaux quant à l'organisation d'audiences adjudicatives et la façon de les mener, surtout dans un cadre tel que le Tribunal du logement de l'Ontario, où sont en jeu les droits de gens vulnérables. Quoique les pratiques de vidéoconférence du Tribunal du logement de l'Ontario n'aient pas encore été contestées, les auteurs concluent qu'éventuellement la conjoncture des ressources du tribunal et de l'équité et l'aspect raisonnable du processus de décision de ce tribunal va parvenir à la cour. La façon dont les cours règleront ces contestations pourrait devenir le prochain domaine d'exploration du droit administratif.

\section{INTRODUCTION}

Administrative law is traditionally concerned with procedural fairness on the one hand and substantive rationality on the other. How the legislature chooses to structure and authorize decision-makers is generally taken to be a matter of political preference rather than legal sufficiency. The same may be said for the decisions of government as to the budget of those tribunals. So, for example, whether a court believes a tribunal may be underfunded or given an ill-suited mandate to its expertise ought not to play a part in whether the decisions of that tribunal are upheld or quashed on judicial review. However, at some point, the structure and resources of a tribunal inexorably brush up against the fairness and rationality of that tribunal's decisions. If, for example, a tribunal decides to save money by not producing transcripts of its hearings or failing to provide adequate space for hearings or not allowing reasonable access to its prior decisions, these administrative decisions cannot be neatly disentangled from adjudicative outcomes. We consider this broad issue from a narrow perspective, that of the experience of a landlord/tenant adjudicative tribunal and its use of videoconferencing, in part to reduce the cost of holding hearings involving residents of communities outside large, urban centres. While the focus is narrow, the issues raised by this examination are broad - we argue that as a general proposition, it is neither sustainable nor desirable to sever questions of tribunal funding and structure from the question of fairness and reasonableness of tribunal decision-making. We do not suggest that Courts should take leadership over policy preferences or spending priorities, but rather that the principles of administrative law should provide guidance and (in some circumstances) constraints on how governments undertake their preferences and priorities. 
Another aspect of this paper is to consider the intersection of videoconferencing and adjudication. This technology has generated considerable interest and a reaction best described as profoundly ambivalent from the legal community. On the one hand, this technology promises unprecedented levels of access to administrative decision-making, especially in rural jurisdictions in Canada characterized by sparse populations and vast geography. In the criminal justice setting, videoconferencing may save significant resources now expended on transporting prisoners for court appearances and witnesses for criminal proceedings. On the other hand, videoconferencing may serve as an expedient justification for consolidating hearing venues for tribunals and almost by definition reduce opportunities for connection and contact as part of the hearing process. Videoconferencing also creates a potentially deleterious reliance on technology which has proven uneven. Even small, technical matters such as the ability of a camera to capture everyone in a room rather than a single speaker can have a substantial impact on the ability of a party or decision-maker to fully understand and fully participate in proceedings.

The case study for this analysis will be the Ontario Rental Housing Tribunal [OHRT] (now renamed the Landlord and Tenant Tribunal), which has the highest caseload by volume of any adjudicative tribunal in the country. Largely as a cost-saving measure, it has embraced videoconferencing for hearings outside major urban centres such as Toronto and Ottawa. We ask the question of whether this practice infringes the duty of fairness (under either common law or Charter standards) and further, whether a court by way of remedy, assuming an infringement of a fairness obligation could be established, could compel the government to provide more funding to the tribunal for in-person hearings or other alternatives to videoconferencing.

Videoconferencing, and the use of video for witness testimony in particular, clearly has progressive potential. Rather than have a child victim of an assault relive the trauma of the assault by having to recount her or his experience before the accused person, videoconferencing allows for the child to be examined or even cross-examined from a secure and more comfortable location. ${ }^{1}$ Experts who could not be flown in to a trial could, through the use of video technology nonetheless participate in a hearing. ${ }^{2}$ In many instances, this enhances the opportunity for a fair hearing. When used as the norm, however, rather than as a response to a particular need, many of the benefits of an oral hearing may be jeopardized.

This paper is divided into three sections. The first section of the paper explores the OHRT with a view to the importance of resources in addressing

1 Criminal Code R.S.C. 1985 c. C-46, S.715.1 allows a complainant under the age of 18 to testify by videotape in relation to offences involving child molestation or sexual assault. The videotape must be made within a reasonable time after the alleged offence, and is only admissible in evidence if the complainant adopts the contents of the videotape when testifying in court. Section $486(2.1)$ of the Criminal Code allows the presiding judge in similar cases to order that a complainant or witness under the age of 18 give testimony outside of the courtroom or behind a screen so that the complainant or witness does not have to see the accused, if this exclusion is necessary to obtain a full and candid testimony.

2 See Innisfil (Township) v. Vespra (Township), [1980] 2 S.C.R. 145, where cross-examination was alleged to be denied because an out-of-town expert was not produced for cross-examination. 
the volume, complexity and vulnerability of parties which characterize its hearings. The second section considers the judicial response to the use of video technology in the adjudicative process. While this issue has not been considered in the context of challenges to the ORHT, our analysis proceeds by examining analogous judicial settings and administrative tribunal settings which have been the subject of judicial commentary. The third section of the paper explores the degree to which procedural or substantive public law principles may constrain the resource allocation to tribunals such as ORHT.

\section{THE ONTARIO RENTAL HOUSING TRIBUNAL: THE RESOURCES OF JUSTICE}

The ORHT holds three types of hearings: hearings where the landlord and tenant appear before the tribunal, electronic hearings conducted by telephone or videoconference, and written hearings where the landlord and tenant submit their evidence in writing to the tribunal. The ORHT is one of Ontario's "quasi-judicial" tribunals, created with the enactment of the Tenant Protection Act in June, 1998. ${ }^{3}$ The Act gives residential landlords and tenants specific rights and obligations, and sets out a process from how these rights and obligations can be exercised and enforced. ${ }^{4}$ The role of the Tribunal is to resolve disputes between landlords and tenants, regulate rent increases, and educate landlords and tenants about their rights and obligations. ${ }^{5}$ Members are appointed to the tribunal by the Ontario Government for specific terms. The Tribunal is currently composed of one Chair, seven Vice-Chairs, thirtytwo Tribunal members and twelve part-time members. ${ }^{6}$

According to Rule 20 of the ORHT rules, the tribunal may consider several factors when deciding whether an electronic hearing will be appropriate. These are: the number of parties to the proceeding, the suitability of the technology for the subject matter of the hearing, the nature of the evidence including whether credibility is at issue, the extent to which the matters in dispute are questions of law, the convenience of the parties and the cost, efficiency and timeliness of the proceedings.

The ORHT has come under fire in recent years for real and perceived injustices. In the 2004 Ombudsman Ontario Annual Report, Clare Lewis wrote in the Ombudsman's Message there were shortcomings to the Tenant Protection Act. The Ombudsman emphasized that eviction can have severe consequences on individuals and families, and that the Act's default eviction process may be having a disproportionate effect on vulnerable tenants such as seniors, single parents with small children, people with disabilities, and

3 Tenant Protection Act, 1997, S.O. 1997, c. 24, s.157.

4 "About Us" Ontario Rental Housing Tribunal online: <http://www.orht.gov.on.ca/userfiles/ HTML/nts_3_5224_1.html>.

5 Ibid. The Ontario Rental Housing Tribunal (ORHT) was renamed the Landlord and Tenant Board with the passage of the Residential Tenancies Act, S.O 2006, c.17, which came into force January 31, 2007. Because the Tribunal was known as the ORHT during the period of this research, we have retained this name for the Tribunal in the discussion.

6 "Members" Ontario Rental Housing Tribunal online: <http://www.orht.gov.on.ca/userfiles/ HTML/nts_3_6153_1.html>. 
those for whom English is a second language. ${ }^{7}$

The Tribunal's discretion in deciding whether to hold an in-person or videoconference hearing is also considered by some as a shortcoming that can similarly have severe effects on those affected. The essential question for the purposes of this paper is whether a videoconference hearing held against the wishes of one of the parties would violate the standards of procedural fairness. The resources in the Northern region of Ontario are currently such that ORHT hearings will generally take place by telephone or videoconference, unless there are exceptional circumstances that would dictate otherwise. In the North, considerations of cost and convenience will thus almost always outweigh the other Rule 20 considerations. To what extent may the other considerations under Rule 20 be sidelined before their irrelevance will result in a violation of procedural fairness? If the statute changed and a videoconference hearing could be held no matter what factors were involved, could the decision be challenged for being in violation of procedural fairness?

\section{A. Prevalence of Videoconference Hearing}

The region of Northern Ontario is comprised of nearly $90 \%$ of Ontario's land area, covering over 800,000 square kilometers. Despite its size, Northern Ontario, with a population of approximately 786,440 , is home to only $7 \%$ of Ontario's population. ${ }^{8}$ Face-to-face hearings are rare, videoconference and telephone hearings being the norm. ${ }^{9}$ Outside of Northern urban centres such as Sudbury and Thunder Bay, depending on the location, videoconference hearings are scheduled bi-weekly (North Bay, Sault Ste. Marie), Monthly (Dryden, Hearst, Kenora, Kirkland Lake, Timmins) and bi-monthly (Elliot Lake, Fort Frances, Nipigon, Espanola, Geraldton, Wawa).

The costs of videoconferencing vary, and the Ontario Rental Housing Tribunal does not track the cost of an individual hearing. The Tribunal however does track overall costs. The Tribunal will generally schedule a hearing block two months in advance, and facilities are usually booked for two-and-a-half hours. The Tribunal pays $\$ 200.00$ per hour to rent videoconference sites, plus a $\$ 50.00$ scheduling fee, plus $\$ 2.52$ per minute for long distance charges. The average cost of each hearing block is thus between $\$ 1,500.00$ and $\$ 1,700.00$, the variable being long distance charges. In 2003, the Tribunal spent over $\$ 200,000.00$ on videoconference facility rental. ${ }^{10}$

There are relatively few ORHT hearings in Northern Ontario, compared to the amount of hearings in the rest of the province. However, of the total

7 Ombudsman Ontario Annual Report 2004, Ombudsman Ontario online: <http://www. ombudsman.on.ca/smuploads/OmbudsmanEngAR04.pdf $>$ at 2-3.

8 "Northern Ontario Overview" Ministry of Northern Development and Mines online: <http:// www.mndm.gov.on.ca/mndm/nordev/redb/sector_profiles/northern_ontario_e.pdf> at p. 1.

9 While the focus of this paper is on videoconference hearings, it must be noted that numerous Northern ORHT hearings, particularly for disputes in the most remote regions, are conducted by telephone. These hearings are most often conducted by tribunal members in the Southern and Eastern regions of Ontario. Between January 9 and July 14, 2006, 229 telephone hearings were conducted for the remote areas of Atikokan, Ear Falls, Kenora, Dryden, Red Lake, Fort Frances, Sioux Lookout, Timmins and Hudson, among others.

10 Letter dated June 7, 2005 from Tony Durbacz, District Manager of the Ontario Rental Housing Tribunal, Sudbury. The letter is on file with the authors. 
Northern hearings, a significant proportion is by videoconference. Between March 7, 2005 and July 1, 2005, there were a total of 573 scheduled ORHT hearings in the Northern Region. Of the total Northern hearings, 120, or $20.9 \%$, were videoconference hearings. Videoconference hearings were not scheduled every week, but on nine days throughout these seventeen weeks. On the days that videoconference hearings were held, they accounted for anywhere between $18 \%$ and $100 \%$ of the Northern hearings scheduled that week. ${ }^{11}$

According to the representatives at the ORHT Northern office, videoconferencing allows the ORHT to "regularly service remote centers" for hearings. Due to the vast geographical area of Northern Ontario and the small number of tribunal members available, the ORHT feels that videoconference hearings allow disputes to be more promptly heard. When the ORHT focused on providing face-to-face hearings in all locations, some applicants had to wait months for their scheduled hearings and tribunal members had to travel long distances to conduct the hearings. ${ }^{12}$

At the beginning of 2006, videoconferencing seemed set to continue as usual. Between January 3 and March 17, 2006, 75 of the 423 scheduled Northern hearings, or $17.7 \%$, were videoconference hearings. Since April 2006 however, there has been a dramatic drop in the number of videoconference hearings, with the proportion of videoconference hearings for the year dropping to $8.9 \%$ by July 14,2006 . This dramatic drop in the proportion of videoconference hearings is due to the suspension of videoconference hearings in Sault Ste. Marie. The ORHT held only videoconference hearings in Sault Ste. Marie for many years, conducting the hearings from the local community college. However, in March 2006, there was a strike at the college, and all scheduled videoconference hearings were cancelled. The ORHT made arrangements for two tribunal members located in Sudbury to attend hearings in Sault Ste. Marie every two weeks since April. This arrangement is expected to continue for the foreseeable future. ${ }^{13}$ Videoconference hearings in North Bay were phased out because they were thought to be too difficult, and were found to be more expensive than conducting in-person hearings in North Bay. ${ }^{14}$

Despite the current drop in videoconference hearings, the enactment of the Residential Tenancies Act, 2006 may trigger a significant increase in the amount of videoconference hearings. Section 242(2) of this Act abolishes default orders that were permissible under s.192 of the Tenant Protection Act, 1997. ${ }^{15}$ Without default orders, more hearings will have to be held, which will likely lead to more videoconference hearings as well.

While the following observations of videoconference and in-person hearings are not intended to present a complete picture, the differences noted between videoconference and in-person hearings may have a sometimes subtle and sometimes profound impact on the fairness of the hearing. As

11 Statistics calculated from weekly ORHT dockets.

12 Letter from Tony Durbacz, supra note 10.

13 Communication date July 14, 2006 from Wendy Bird, Community Legal Worker at Algoma Community Legal Clinic, Sault Ste. Marie. On file with authors.

14 Communication from Stuart Bailey, Legal Aid Ontario, July 19, 2006.

15 Supra note 8. 
discussed below in greater detail, a party's ability to maintain eye contact with a decision maker, the ability to approach the decision maker in private and the ability to present documents for the decision maker's immediate perusal are all missing from videoconference hearings. The absence of these "privileges" routinely available at in-person hearings may make videoconference hearings appear less fair than in-person hearings.

\section{B. Anatomy of a Videoconference Hearing}

In order to assess the fairness of video hearings generally, it is important to understand the logistics and complexity involved first-hand. Such first hand accounts of the administrative justice adjudicative settings are rare. The following is a first-hand account by one of the authors of a videoconference session in the city of North Bay in the Northern Region of Ontario that took place in the summer of $2005 .{ }^{16}$

July 12, 2005

North Bay, Ontario

The hearings took place at Cannadore College, which is about a ten minute highway drive from the North Bay city centre. The College is also accessible by bus. We entered the building through the main entrance. On a wall to our left there was a whiteboard upon which was written "O.R.H.T. - Room 135" in red marker. We followed duty counsel through a maze of hallways to Room 135. There was nobody there to greet us or show us the way. The College was almost deserted.

There was nothing about Room 135 that marked it as a courtroom or hearing room. There was a long blue conference table in the centre of the room, surrounded by steel and upholstered blue chairs. The walls were painted in white and two shades of green, and the pictures on the wall included a map of Northern Ontario and a flying duck. The only things that distinguished the room as a hearing room were the Commissioner seated at the head of the table and the two televisions at the far end of the room. On the television screen directly facing the Commissioner, the adjudicator was silently setting up in Sudbury. On the other screen, left of the first TV, there was a close-up shot of the conference table in North Bay, centred on a place card that read "Contact North - North Bay" and the Commissioner's folded arms.

When we walked in, the chairs around the table were already filled. We took some extra chairs and placed them against the wall. The two chairs at the front of the table on either side of the Commissioner were reserved for the parties to the hearings and thus left empty. Soon all the chairs were taken and the

16 Aside from some comments about the difficult parties present at this particular hearing, duty counsel in North Bay did not express any surprise with the proceedings, giving the impression that this hearing was a routine example of a Northern videoconference hearing, and not out of the ordinary. 
Commissioner had to send for some more. The additional chairs were white plastic and a pile of them were placed at the far end of the room near the TVs. As more people drifted in, they had to lift a chair from the pile and find a place in the crowded room.

At 9:30 AM, the Commissioner turned the sound on in Sudbury where the adjudicator, Gerald Naud, was seated. The adjudicator did not know how to turn on the sound from his end and had to go for some help. Once the sound issue was resolved, the adjudicator could not adjust the zoom function on his end. The second television, which represented the adjudicator's view of the hearing room, remained focused on the Commissioner's arms. The adjudicator again called for help and was finally able to adjust the zoom to a long shot of the room. This shot captured those sitting at the centre of the room, leaving out all those sitting on the sides. The adjudicator did not adjust the camera shot again, so the viewpoint remained the same throughout the hearings.

Problems with the technology, for the purpose of fairness, became quickly apparent. The adjudicator's image was blurry and it was very hard to read any expression on his face. The camera could not capture movement very well either, the image becoming jerky whenever the adjudicator moved. It was therefore difficult to gauge the adjudicator's body language and expression, and difficult to read his mood. It quickly became apparent that the adjudicator had similar difficulty gauging those of us in North Bay. The first concern was that the adjudicator could not identify the people who were speaking. When the adjudicator asked if there was duty counsel present, Duty Counsel stood up and introduced herself, but the adjudicator could not tell who it was that was speaking. This indicates that the video image did not capture oral movement, let alone facial expressions. The adjudicator assumed that duty counsel was a woman sitting at the front of the room in what the adjudicator characterized as an orange suit. The colours on the video screen were distorted as well. The woman at the front of the room was not wearing orange but a salmon colour. People's skin tones were distorted as well, with most people looking decidedly orange. Those sitting at the front of the room near the Commissioner were also the farthest away from the adjudicator's point of view, and their faces were in shadow. This was problematic because the parties to the dispute were told to sit at the front of the room. The images of those seated closer to the TV screens and away from the Commissioner were slightly more defined. Furthermore, unlike an in-person hearing where the parties face the adjudicator, the parties in the videoconference hearing presented the adjudicator with their profiles. To face the adjudicator, people had to turn in their seats. When reading from their files or speaking to other parties, the adjudicator could only see the sides of the parties' faces.

The videoconference hearings were also plagued by a lack of formality and organization that would normally be present in an in-person hearing. There were no place cards marking where the parties were to sit, and therefore no consistency as to how the landlords and tenants placed themselves. Parties simply sat on the Commissioner's side that was closest to them. The relative 
informality may also have contributed to the adjudicator's difficulty in keeping control over the hearings. The first case dealt with a dispute over rental arrears. The parties to the dispute were very emotional, and the tenant kept interrupting both the landlord and the adjudicator. While the sound transmission was almost simultaneous, it did not match with up with the image transmission. Furthermore, since it was difficult to read the adjudicator's expression, it was impossible to tell when he was beginning to speak. This meant that the adjudicator and the parties to the dispute frequently began speaking at the same time, with all three parties talking over each other. The adjudicator eventually lost his cool, banged his fist repeatedly on his table and yelled at the tenant to be quiet. While this was the worst situation of the morning, there were other times when the adjudicator and one of the parties would begin speaking simultaneously. The Commissioner did not involve himself in the proceedings at all, even when things seemed to get out of order. There was a noticeable difference to the proceedings when duty counsel was present. With duty counsel in the room, there were fewer interruptions and the proceedings moved at a faster pace.

Another issue that implicated the fairness of the hearings was the parties' and the adjudicator's inability to exchange documentary information. Some people had documentation and pictures which they wished to bring to the adjudicator's attention, but since there was no fax machine available, the adjudicator could not view the evidence first-hand. In one case, a witness read a letter she had written to her landlord as evidence in an eviction case. In another case, a tenant read out a letter from social services. Where new evidence was introduced, the adjudicator advised the parties to mail copies of the materials to Ottawa at the end of the hearing.

In sum, the videoconference hearings seemed to work very well for procedural and undisputed cases. These cases were dealt with quickly and efficiently, without anyone having to travel very far and with the OHRT assuming minimal costs. For the more complicated cases however, the videoconference hearings seemed to be a poor substitute for in-person hearings, and in some cases seemed to have an impact on the perceived fairness of the hearing.

One of the biggest differences between in-person and videoconference hearings is the formality and visible process of in-person hearings. ${ }^{17}$ At the St. Clair East hearing venue in Toronto on June 24, 2005, there were two officials in uniform greeting people as they came in, instructing parties to sign in, and directing them to the clearly marked hearing rooms. At the front of each room was the decision-makers desk. It was front and centre and closely faced both the appellant and respondent's tables. There were microphones hanging over each table and at the back of the room there was an alcove with hangers so that people could take off their coats in the winter.

The mediator entered the room through a separate door at the back end of the room. The tribunal member present on this particular day was Ms. C. King. ${ }^{18}$ Another notable difference from the videoconference hearing was the

17 These observations of in-person ORHT hearings took place on June 24, 2005, at 79 St. Clair Avenue East in Toronto.

18 It should be noted that in the opinion of legal aid counsel, Ms. King is one of the more sympathetic and fair ORHT tribunal members. 
opportunity to observe the tribunal member and judge her demeanour before the hearings began. Parties were already seated as Ms King set up at the front of the room and introduced herself. Ms. King advised everyone that the docket was heavy and that she would not be able to get through everything that day. She gave the parties present the opportunity to approach her desk and speak with her privately on preliminary matters. This was another aspect of the inperson hearing that was not available in the videoconference hearings.

The first hearing revolved around an issue of credibility, and may have been difficult to adjudicate through a videoconference hearing. The landlord had brought an application to remove a tenant for giving notice to terminate the lease, but the tenant argued that he had verbally agreed with the landlord to delay the termination. Body language was a key aspect of each party's testimony. Each party sat forward and looked directly at the member, trying to catch her eye as she made notes. The tenant was particularly emotional. At one point, frustrated that he was having trouble getting his point across, he banged his hands on the table and then hung his head. It was clear that the tribunal member was having trouble understanding the tenant's side of the story. She asked him numerous times to tell her all the details and to go over the story slowly. Ms. King finally decided in the landlord's favour, not being satisfied that the verbal agreement had been made.

The third hearing involved an application to return a tenant's deposit. The tenant applicant put a lot of effort into his submission. However, he was very nervous and decided to stand throughout his presentation. The tenant brought photographs he had taken to strengthen his position, and was able to bring them directly before the tribunal member, which would not have been possible in most videoconference settings.

Another hearing involved an application brought by a residential home to evict a tenant with a developmental disability. The tribunal member noted that the case was too complicated to be resolved in the limited time left, and rescheduled the hearing for another day. Although the tenant was represented by counsel, the tribunal member made a point of personally addressing the tenant and asking her whether she had someone to call if she had nowhere else to go, and advising the tenant to remain on her best behaviour.

Having these particular hearings conducted by videoconference may have limited fairness to some degree. Particularly in the first case where credibility was at issue, it was very important for the member to be able to assess the parties' behaviour. For the application where the applicant found it more comfortable to stand, it would perhaps have been unfair to make him sit in order to comply with a camera set-up. The tenant also had the ability to forward his case by putting physical evidence before the tribunal member. This would not likely have been possible in a videoconference hearing.

To conclude, the experience of the ORHT with videoconferencing suggests that there is something tangible lost in the shift from an in-person proceeding to one mediated by video. That said, videoconferencing also makes a hearing before the tribunal accessible in a fashion that would not be possible otherwise without significant resources. Is the trade-off between fairness and resources justified in the circumstances? What are the legal limits, if any, which constrain a government or tribunal when it comes to forms of 
hearings or resource allocation in adjudicative settings? It is to this critical question that our analysis now turns.

\section{THE JUDICIAL AMBIVALENCE TO VIDEOCONFERENCING}

The case law on videoconferencing reflects judicial ambivalence and uncertainty as to the role of courts in overseeing the administrative decisions and resource allocations of tribunals. As we discuss below, courts have recognized the advantages and disadvantages of videoconference hearings and an overarching trend is hard to discern. In our view, it is possible to see this issue as a delicate balancing exercise, where justifying the potential loss of fairness or the risk of unreasonable outcomes in light of videoconference hearings is balanced against questions of access, scarce resources and legitimate administrative preferences on the one hand and the seriousness of the issue and impact on the parties on the other.

The judicial ambivalence alluded to above is not hard to find in a review of the relevant case law on videoconference hearings. Courts have expressed appreciation for the obvious advantages of videoconferencing, including reduced costs for transporting inmates to court from jail, and the reduced cost and increased convenience for those who live far away from urban centers. From a judge's perspective, the advantages of videoconferencing include being able to see a witness face-on rather than from an angle, and being able to adjust the zoom level at which the judge may view the witness. However, the courts, public advocates and legal academics have also expressed a deep concern with both the perceived and actual fairness of videoconferencing. Where the videoconferencing technology is poor or credibility is at issue, the courts have resisted cost justifications for substituting a videoconference hearing for an in-person hearing.

This ambivalent response to videoconferencing corresponds to the advantages and disadvantages noted at the North Bay videoconference hearings. Where the matters at issue are relatively simple, videoconference hearings work well, and are convenient and cost efficient for both the parties and the government. However, when the issue is more complicated or where emotions run high, it is no longer clear that the cost and efficiency savings of videoconferencing outweigh the importance of having an in-person hearing. Where videoconference hearings are standard and in-person hearings the exception, as is the case in Northern Ontario, the balance between cost and efficiency and fairness becomes even more precarious. The Tribunal's discretion to hold an in-person hearing instead of a videoconference hearing is necessary for videoconferencing to comply with the standards of procedural fairness.

\section{A. The Advantages}

Courts have highlighted several advantages to holding a hearing by videoconference rather than in person. One advantage is the ability to see the witness face-on and with more clarity. The Yukon Territorial Court in R. $v$. Heynen held that camera angles and close-up views enhance the ability 
to assess demeanour. ${ }^{19}$ The Ontario Superior Court of Justice in Pack-All Manufacturing held that seeing the witness face-on and in full colour is as good, or arguably better than, seeing the witness obliquely from the witness box. ${ }^{20}$ The British Columbia Supreme Court in R. v. Gibson went so far as to say that a well-placed camera may enhance the expressions of a witness under crossexamination. ${ }^{21}$ The Alberta Court of Queen's Bench in R. $v$. Dix held that the technological sophistication of a videoconference facility could safeguard witness reliability. ${ }^{22}$ In other cases, the courts have held that videoconferencing is just as good as an in-person hearing. ${ }^{23}$

Another advantage of videoconferencing is having access to witnesses who would otherwise be unavailable either due to cost or the witness being out of the jurisdiction. In R. v. McLean, a witness living in Nanaimo who did not want to return to the town of Mayo for fear of relapsing into alcohol abuse was permitted to give evidence by remote testimony ${ }^{24}$. In Wright $v$. Wasilewski, Ms. Wright was able to call 20 witnesses to give testimony by videoconference. The cost to Ms. Wright of otherwise bringing those witnesses to court would have been prohibitive..$^{25}$ In R. $v$. Dix, the Crown was able to use videoconferencing technology to have a witness testify before an Alberta court from New York before she left for Great Britain, where she would no longer have been available as a witness. ${ }^{26}$

Videoconferencing can also bring significant cost savings to the courts. In R. $v$. Heynen, one of the first cases where an application to examine witnesses by videoconferencing was considered, the court emphasized that using video technology saves court costs. The court noted that video and audio services should be used as much as possible in the Yukon in order to minimize outlying communities' financial hurdles in accessing courts. ${ }^{27}$ The academic literature emphasizes the cost savings advantages, as well as the advantages in terms of physical safety to both those being tried and the general public. Michael D. Roth demonstrates the sometimes exaggerated cost savings of videoconferencing in his example of the Unabomber's arraignment, which took place in New Jersey while Mr. Kaczynski was being held in Sacramento, California. The estimated cost of transporting Mr. Kaczynski to New Jersey was $\$ 30,000$ while the cost of holding the arraignment by video was $\$ 45 .^{28}$

According to Anne Bowen Poulin videoconferencing allows trials to be open to the public while security costs are kept to a minimum. Prisoners may also avoid the discomfort of being transported to court. Prisoners also

19 [2000] Y.J. No. 6 at para. 315 (Yk.Terr.Ct.) (QL)[Heynen].

20 Pack. All Manufacturing Inc. v. Triad Plastics Inc. [2001] O.J. No. 5882 at para. 6 (On.Sup.Ct.) (QL) [Pack-All Manufacturing].

21 [2003] B.C.J. No. 812 at para. 5 (B.C.S.C.) QL).

22 [1998] A.J. No. 486 at para. 24 (A.B.Q.B.) (QL) [Dix].

23 See Maggio Holding [2003] O.J. No. 1810 (On.Sup.Ct.) (QL), J.S. v. Canada [2003] S.J.No.44 (Sk. Q.B.) (QL).

24 [2002] Y.J. No. 88 at para. 18 (QL).

25 (2001) 52 O.R. (3d) 410 at paras 5, 12 (On.Sup.Ct.). The cost of bringing these witnesses from the U.S. to Toronto would have amounted to $\$ 20,000$.

26 Dix, supra note 22 at para. 1.

27 Heynen, supra note 19 at para. 321.

28 Michael D. Roth, "Laissez-Faire Videoconferencing: Remote Witness Testimony and Adversarial Truth” (2000) 48 UCLA L. Rev. 185 at 190. 
have the benefit of being released earlier if the court orders a release by videoconference. Finally, more cases can be handled in a shorter amount of time with the available court personnel. ${ }^{29}$ Gerald G. Ashdown and Michael A. Menzel point out that videoconferencing reduces judges' travel time in large districts and reduces the inconvenience to lawyers and witnesses of appearing in court. ${ }^{30}$ Robin Widdison mentions other advantages of videoconferencing. According to Widdison, videoconferencing may even enhance the ability to assess credibility because of high quality sound reproduction, action replays, and the ability of the judge to view the witness from different angles. ${ }^{31}$

\section{B. The Disadvantages}

In spite of the numerous advantages of videoconferencing, courts have also recognized some significant shortcomings of videoconferencing. Videoconferencing technology may not always be of a standard high enough to guarantee fairness. In R. $v$. Raj, the court agreed with the defendant's assertion that the video link made it difficult to assess body language and discern expressions. Furthermore, there was only a single camera angle available, and there was a delay between the questions and the witness' answers. The court concluded that these defaults in the technology impaired the defendant's ability to make full answer and defence and rejected the use of videoconferencing in that case. ${ }^{32}$ In R. $v$. Gates, the court concluded that video equipment which did not allow the parties to see and speak to each other simultaneously violated s.650 of the Criminal Code, which requires the accused to be present at all stages of the trial. ${ }^{33}$

In de Upegui v. Canada (Minister of Citizenship and Immigration), ${ }^{34}$ the Court noted that videoconferencing did not afford the applicant a fair hearing. The Court held that given the applicant's circumstances, combined with the conditions of the hearing, it was unreasonable for the Board, for the reasons it gave, to conclude that the applicant's testimony was adjusted because she was lying. The Court noted:

In its reasons, the Board referred to Ms. Gomez as being "visibly nervous" while testifying and it "found her attitude disconcerting." A review of the transcript shows that Ms. Gomez was confused and agitated while giving her testimony. The hearing was not assisted by the fact that it was held by videoconference. Nor was the hearing assisted by the very frequent interjections of the interpreter who, in addition to seeking various clarifications from counsel and the presiding member, thought it necessary to

29 Anne Bowen Poulin, "Criminal Justice and Videoconferencing Technology: The Remote Defendant” (2004) 78 Tul. L. Rev. 1089 at 1098-1101.

30 Gerald G. Ashdown \& Michael A. Menzel, "The Convenience of the Guillotine?: Video Proceedings in Federal Prosecutions" (2003) 80 Denv. U. L. Rev. 63 at 66.

31 Robin Widdison, "Beyond Woolf: The Virtual Court House", online: Proceedings of the Twelfth British and Irish Law, Education and Technology Association, 1997 at 4 <http://www.bileta. ac.UK/pages/conference $\% 20$ papers.aspx $>$

32 [2002] B.C.J. No. 678 at paras. 5-6 (B.C.S.C.) (QL).

33 [2002] B.C.J. No. 416 at paras. 16-17 (B.C.C.A.) (QL) [Gates].

34 [2007] F.C.J. No. 369 (F.C.) (QL). 
provide a running commentary to the presiding member, noting at one point that Ms. Gomez was crying and at another point volunteering:

I must say for the record, Madame Member, that claimant at times is doing faces as she assumes I don't know if it's the interpreter or all of us that she would understand what she means without herself even saying. I don't know how to put it exactly, but I should, I think say that for the record. Even I sense some surprise on the part of claimant that she's being asked questions as if things should be so evident that there should be no questions. Something like that, Madame Member. ${ }^{35}$

The Court in de Upegui advised that in the "very unique and special circumstances of this case...the Board make every effort to see that the redetermination hearing is not held by videoconference."36

The literature goes more into depth on the disadvantages of videoconference technology and the unfairness that may arise as a result. Cormac T. Connor notes that a video image is only as good as what it captures. Bad camera angles, zooms and lighting can all have negative effects on an adjudicator's ability to fairly assess witnesses. Videoconferencing also restricts emission of body language signals and makes eye contact, an important factor in assessing credibility, impossible. ${ }^{37}$ Anne Bowen Poulin emphasizes that technology is never neutral, and the subtle effects of technology are incredibly important when justice is at stake. Inaccurate impressions may be made due to an unfavourable camera shot, and non-verbal cues may be lost or distorted. Videoconferencing cannot replicate normal eye contact either, which is important in influencing people's interactions and perceptions of each other. The technology also skews physical appearance, upon which a lot of discretionary decisions are made. ${ }^{38}$ Elizabeth C. Wiggins notes that seemingly inconsequential changes in camera perspective may significantly alter evaluations of videotaped confessions. Even judges who have experience hearing confession evidence are subject to this effect. Information about the emotional state of the speaker may also be inaccurately transmitted through videoconference. A middle bandwidth filter is used when auditory information is transmitted through phone lines cutting off low and high frequencies. However, information about the emotional state of the speaker is often carried in the higher frequencies, and may be critical to findings of credibility. ${ }^{39}$

Corresponding to the concern of videoconference technology is the concern that a videoconference session should include all the necessary

\footnotetext{
Ibid. at para. 5 .

6 Ibid. at para. 8.

37 Cormac T. Connor, "Human Rights Violations in the Information Age" (2001) 16 Geo. Immigr. L.J. 207 at $216-218$.

38 Poulin, supra note 28 at 1106-1111.

39 Elizabeth C. Wiggins, "What We Know and What We Need to Know about the Effects of Courtroom Technology” (2004) 12 Wm. \& Mary Bill Rts. J. 73 at 737-738.
} 
technology complementary to a video link. The court in Pack-All Manufacturing noted that a fax machine is necessary in videoconference hearings in order to exchange documentation. ${ }^{40}$ As noted in the account of the videoconference hearing in North Bay, without a fax machine, adjudicators may not review new documentary evidence and assess the credibility of that evidence at the time of the hearing.

The concern that videoconference technology will negatively impact credibility assessments is also a recurrent theme in the case law. The court in Lena v. Kamploops held that a personal audience before the court may not always be necessary, and that hearings may be conducted in writing or by telephone or videoconference. However, the court emphasized that where there is an issue of credibility, or where a witness must handle an exhibit, holding a hearing by videoconference may be unjust. ${ }^{41}$ In $\mathrm{R} . v$. Fleury, the court held that it would be potentially prejudicial to the accused if a witness were not cross-examined in person when credibility was at issue. ${ }^{42}$ Finally, the court in R. $v$. Chapple held that where credibility is at issue, the court should be very reluctant to forego having a witness physically present in court. ${ }^{43}$

One seemingly irresolvable dilemma of videoconference hearings is the defendant's inability to be effectively represented. In Rusu v. INS this dilemma is characterized as a Catch-22 situation. If the lawyer is present on video with the client, he can effectively advise his client but may not be able to effectively interact with the judge. If the lawyer is present in the courtroom, he forfeits the ability to privately advise his client. ${ }^{44}$ This problem is revisited several times in the literature on the subject. In the criminal law context, Ashdown and Menzel note that videoconferencing forces defense counsel to decide between being in court with the judge and prosecutor or with the client. ${ }^{45}$ According to Elizabeth C. Wiggins, whatever choice defence attorneys make - to be with their client or be present in the courtroom - their decision may interfere with the defendant's right to adequate representation. ${ }^{46}$

Finally, videoconference hearings may fundamentally challenge perceptions of fairness. In R. $v$. Gates, the court noted that the technological problems experienced with videoconferencing are not minor problems but affect the fairness of the entire proceeding. In United States $v$. Baker, the court held that an in-person hearing is important because it gives the accused an opportunity to make a good impression before the judge. Videoconferencing undermines this ability and thereby the applicant's confidence in the impartiality and fairness of the hearing ${ }^{47}$. In R. $v$. Fecteau the court emphasized that the human element of the courtroom is of the utmost importance.

It is one thing for a judge to sentence to imprisonment a live human being who stands physically before the judge in open court.

40 Pack-All Manufacturing, supra note 20 at para. 8.

41 Lena v. Kamloops Regional Correctional Centre [2000] B.C.J. No. 2262 at para. 26 (B.C.S.C.) (QL).

42 [2004] S.J. No. 242 at para. 17 (Sk.Prov.Ct.) (QL).

43 [2005] B.C.J. No. 585 at para. 52 (B.C.S.C.) (QL).

44 (2002), 296 F (3d) 316 at 322-323 [Rusu].

45 Ashdown and Menzel, supra note 29.

46 Wiggins, supra note 38 at 737.

47 (1995) 45 F. 3d 837 at 845 
The judge, before imposing a term of imprisonment, at least has to look the accused in the eye. It may be quite another thing to sentence to imprisonment a disembodied television image that appears on a screen on the judge's dias $\left(\right.$ sic ${ }^{48}$

In the context of the ORHT, the concern may be a similar lack of a human element in depriving people of their homes.

The academic literature on videoconference hearings also emphasizes the more abstract fairness issues engaged by long-distance justice. Frederic Lederer points out that this loss of humanity is videoconferencing's ultimate threat. Virtual trials threaten the solemnity of the courtroom. Furthermore, respect for the law and justice would suffer if the public were to feel that the system is becoming unfair. ${ }^{49}$ Ashdown and Menzel also note that videoconferencing undermines the solemnity of court proceedings. They emphasize that the form and process of the judicial system are more than mere trappings. Form and process are the pillars that support the structure of the justice system just as ceremony and ritual reinforce the solemnity of religious practice. According to Justice Joseph Goodwin, the court's moral authority rests on the public perception that its proceedings are fair and just. Justice Goodwin has expressed concern that videoconferencing will tarnish the public's view of the integrity of the judicial process, thus calling the court's authority into question..$^{50}$ According to Nancy Gertner, there is a certain formality attached to courtroom proceedings that is lost through videoconferencing. ${ }^{51}$ However, Gertner allows that formality may not always be desirable, depending on the context and circumstances of an individual's case. ${ }^{52}$

When examined on a case by case basis, the implications in the use of video for the fairness of a hearing may depend on a number of factors. What this contextual review, which is typical of how the issue arises for courts, does not consider, is the broader policy discretion to introduce video hearings as a cost-saving measure. Few would disagree that in certain circumstances, video has the potential to compromise the fairness of a hearing. In light of the fact that video may compromise the fairness of a hearing, the question becomes when is a video hearing justified? It is hardly controversial to suggest that it is justified where there are specific benefits (e.g. protecting a juvenile witness from having to face an accused in open court). The controversy arises, in our view, when one asks whether the use of videoconference hearings, and the attendant risk of unfair or unreasonable outcomes, may be justified as a measure to save money while providing access to more remote population centres. To what extent can and should procedural fairness obligations constrain the state's allocation of resources to adjudicative administrative bodies? It is to this question that we now turn.

48 (1989) 71 C.R. (3d) 67 at para. 27 (On.Sup.Ct.)

49 Frederic I. Lederer, "The Road to the Virtual Courtroom? A Consideration of Today's - And Tomorrow's - High-Technology Courtrooms" (1999) 50 S.C.L. Rev. 799 at 28 [Lederer, "The Road to the Virtual Courtroom"].

50 Ashdown and Menzel, supra note 29 at 68.

51 Nancy Gertner, "Videoconferencing: Learning Through Screens" (2004) 12 Wm. and Mary Bill Rts. J. 769 at 784.

52 Patricia J. Williams, The Alchemy of Race and Rights (Cambridge: Harvard University Press, 1991). 


\section{PROCEDURAL AND SUBSTANTIVE CONSTRAINTS ON RESOURCE ALLOCATION FOR TRIBUNALS}

In light of the analysis above of the ORHT and the judicial response to videoconferencing generally, in this section we ask, under what circumstances, if any, would a decision to hold an ORHT hearing by videoconference in order to save the costs of an in-person hearing be deemed procedurally unfair or substantively unreasonable by a Court?

\section{A. Procedural Fairness Constraints}

The first question is whether videoconferencing can serve as a substitute for an in-person hearing so as to satisfy an applicant's right to be heard where an oral hearing is required.

The content of procedural fairness is variable and will be decided on a case-by-case basis. ${ }^{53}$ According to Khan v. University of Ottawa, a full oral hearing will be required where credibility is at issue. ${ }^{54}$ Depending on the case at hand and the level of procedural fairness required, it may be that a videoconference hearing will suffice to fulfill the requirement of a full oral hearing. However, where the level of procedural fairness required is high, it is not clear that videoconferencing will be considered fair. The question is whether the technology is accepted as a viable alternative to an in-person hearing. In other words, video does not necessarily meet or infringe this sort of standard. The burden lies on the aggrieved individual to demonstrate an infringement. In order to discharge this burden, it will be necessary to establish that video either is inherently less fair than in-person hearings or specifically so in a given case in light of the circumstances.

According to Fred Lederer, experimental work done by the Courtroom 21 project shows that when done properly, videoconference hearings are an effective substitute for in-person testimony. ${ }^{55}$ However, the majority of the academic commentary on the issue disagrees with this point of view, emphasizing that videoconferencing should not be considered such a substitute. In Ruminations, Lederer concludes that absent extreme necessity or reliability, courtroom technology should not be used for fear of violating the social contract. According to this contract, efficiency may not be achieved at the cost of acceptance for fear of a loss of legitimacy. ${ }^{56}$ In another article, Lederer notes that it is unclear whether the population is prepared to interpret live, electronically conveyed testimony as the human equivalent of in-court testimony. ${ }^{57}$ Some authors are unequivocal in their opinion that video presence is not an adequate substitute for physical presence.

53 See Baker v. Canada (Minister of Citizenship \& Immigration) [1999] 2 S.C.R. 817: The content of procedural fairness will vary depending on the nature of the decision being made, nature of the statutory scheme, importance of the decision to the people affected, legitimate expectations and agency's choice of procedures

54 (1997), 34 O.R. (3d) 535 (C.A.)

55 Frederic I. Lederer, "Ruminations on Public and Professional Perceptions of TechnologyEnabled Dispute Resolution and Their Effects" Courtroom 21 Court Affiliates Conference, San Francisco, CA, May 2005 at 6 [Lederer, "Ruminations"]

56 Ibid. at p. $15,9$.

57 Lederer, "The Road to the Virtual Courtroom," supra note 47 at 28. 
Gerald G. Ashdown and Michael A. Menzel note that while attending a videoconference hearing is better than not attending any proceeding at all, it is not as good as being physically present in the courtroom. Presence exists along a gradient and video presence should be considered as a class in itself. ${ }^{58}$ The essential question thus becomes whether due process and the appearance of fairness can be maintained through the use of videoconferencing. The authors conclude that whatever the answer to this question, videoconferencing should be allowed in clear, general circumstances where special circumstances exist and the interests of justice warrant its use..$^{59}$ According to Nancy Gertner, there is a clear difference between videoconferencing and face-to-face communication. Personal communication allows you to observe things about people you would not otherwise see through a camera. There is also a certain formality attached to the courtroom that is lost through videoconferencing. ${ }^{60}$ Face-to-face testimony increases the information available to the trier of fact. ${ }^{61}$

The opinion that videoconferencing cannot substitute for in-person hearings, is echoed in the case law. The British Columbia Supreme Court in R. v. Chapple held that s.714.1 of the Criminal Code, which allows videoconferencing, does not replace the established procedure of having witnesses appear in court. Rather, the rule supplements normal practice and allows the use of technology where appropriate. ${ }^{62}$ To determine where videoconferencing will be appropriate, the judge must consider the nature of the evidence. Where credibility is at issue, a judge should be very reluctant to deprive herself of the chance to see the witness in person before her. ${ }^{63}$ In Pack-All Manufacturing v. Triad Plastics, the Ontario Superior Court of Justice held that videoconferencing may take place where the advantages of the technology overcome the traditional rule that evidence be given in person in court. $^{64}$ In Rusu v. INS, the court quoted from the decision in R. v. Lawrence where the court held that "virtual reality is rarely a substitute for actual presence and ... even in an age of advancing technology, watching an event on the screen remains less than the complete equivalent of actually attending it." ${ }^{\prime 65}$ The court in Rusu also quoted from the decision in Edwards v. Logan, where the court held that "[v]ideo conferencing ... is not the same as actual presence, and it is to be expected that the ability to observe demeanor, central to the fact- finding process, may be lessened in a particular case by video conferencing. This may be particularly detrimental where it is a party to the case who is participating by video conferencing, since personal impression may be a crucial factor in persuasion." ${ }^{\prime 66}$

A side issue is whether videoconferencing can satisfy procedural fairness at all, and whether it can satisfy hearing requirements where oral hearings are not necessary. There is no objection in the case law to videoconferencing

58 Ashdown and Menzel, supra note 29 at 69, 105.

59 Ibid. at 109.

60 Gertner, supra note 49 at 783-784.

61 Ibid. at 786.

62 Chapple, supra note 42 at para. 50.

63 Ibid. at para. 52.

64 Pack. All Manufacturing, supra note 20 at para. 11.

65 Rusu, supra note 43 at 322.

66 Ibid. at p. 322. 
where an oral hearing is not otherwise required. However, a question is raised in the literature as to whether videoconferencing can ever be fair because it admits factors that would otherwise be excluded in telephone and written hearings. According to William R. Anderson, videoconferencing is a new technology and may intimidate people, negatively affecting their presentation. Compared to video technology, the telephone is familiar and non-threatening, can be used in the convenience of one's home and does not let personal appearance, dress or environment become factors in the case. ${ }^{67}$ This suggests, however, that as video phones, web cams and related technology become commonplace, such concerns may fade. Technological representations of individuals, however, still cannot be equated to in-person encounters. According to Michael D. Roth, video can exaggerate personal traits that are commonly used to evaluate demeanour, such as blemishes, shadows and hair growth. Video can add weight and emphasize scars. ${ }^{68}$

To summarize, videoconferencing will more often than not diminish the fairness of a proceeding. For the many reasons set out above, however, it will not do so in every case. Thus, it would be difficult to suggest that the move to video hearings by ORHT in the Northern Region could, as a whole, be impugned on fairness grounds alone.

\section{Issue of Fettering Discretion}

In Northern Ontario where there is arguably no option to have an inperson hearing because of the funding and administrative decisions of the Tribunal, can it even be said that decision makers exercise discretion in deciding when an electronic hearing will be appropriate? If a Tribunal has the statutory discretion to hold hearings in person or electronically, but it is not open for a tribunal to hold in-person hearings in certain regions due to a policy direction or resource constraints, it is arguable that the tribunal's discretion has been fettered improperly. ${ }^{69}$ This also can negatively affect the independence of tribunal members, who may feel pressured to find that an electronic hearing will cause no significant prejudice where there is no practical alternative.

\section{Issue of Misuse of Discretion}

In addition to the issue of fairness and the fettering of discretion, the decision to hold a hearing by videoconference may itself represent the misuse of a discretionary power.

Discretion is never absolute and always implies good faith and acting in a fashion consistent with a decision-maker's enabling statute. ${ }^{70}$ The exercise of discretion is characterized by one, whether the language of discretion is used, two, the nature of the interests being protected given the consequences of the decision, and three, the character of the decision-maker, i.e. whether they

67 William R. Anderson, "Technology and the Washington State Administrative Process - Some Preliminary Notes” (2004) 79 Wash. L. Rev. 13 at 19.

68 Roth, supra note 27 at 198.

69 See Thamotharem v. Canada (Minister of Citizenship and Immigration) 2007 FCA 198, discussing the validity of a guideline encouraging the reverse order of submissions by the parties, as long as the tribunal members retain the ability to waive the policy in appropriate circumstances.

70 Roncarelli v. Duplessis [1959] S.C.J. No. 1 (QL), Baker v. Canada (Minister of Citizenship and Immigration) [1999] S.C.J. No. 39 (QL), CUPE v. Ontario (Minister of Labour), [2003] 1 S.C.R. 539. 
have the appropriate expertise. In the context of the OHRT, the language of discretion is used. According to Rule 20.1 of the ORHT rules, in deciding whether to hold an electronic hearing, a Tribunal may consider any relevant factors, including (a) the number of parties to the proceeding, (b) the subject matter of the hearing, (c) whether credibility is at issue, (d) the extent to which the matters in dispute are questions of law, (e) the convenience of the parties and (f) the cost, efficiency and timeliness of the proceedings.

According to Rule 20.2, a party who objects to an electronic hearing must set out how an electronic hearing would cause them significant prejudice. These provisions are significantly permissive, giving the Tribunal the discretion to consider these factors or not. There is no provision that these factors must be considered once an application is made under rule 20.2 either. However, according to Rule 5.2(2) of the Statuary Powers Procedure Act [SPPA], a Tribunal shall not hold an electronic hearing if a party satisfies the Tribunal that holding an electronic rather than an oral hearing is likely to cause the party significant prejudice. This rule reduces discretion somewhat, but not by much. The Tribunal must still be satisfied that an electronic hearing will cause significant prejudice, and this will be measured by the permissive criteria set out in Rule 20.1. Depending on the case before the Tribunal, the nature of the interests protected may be significant. Finally, it is supposed that the decision-makers on the Rental Housing Tribunal will be held to have the appropriate expertise. It will therefore be difficult to find an abuse of discretion where a Tribunal decides to hold an electronic hearing as opposed to a hearing in person.

While it may be possible for Tribunal members to avoid a judicial review on this basis, if a decision-maker did justify the recourse to an electronic or video hearing solely on the grounds of government or tribunal direction to save money, this could (and, in our view, should) be grounds to invalidate the decision as an unreasonable exercise of the decision-maker's discretion. The decision-maker has a statutory obligation to consider a range of factors but the available resources of the tribunal or the government, significantly, is not one of them.

\section{B. Charter constraints}

Where the Charter threshold is met (that is, the s.7 standard of a right to life, liberty or security of the person), this provides an additional constraint on government or tribunal preferences, and one which cannot be superceded by more express legislative direction. Once the threshold is met, the content of the Charter's procedural fairness obligations are similar (if not identical) to the common law fairness obligations. ${ }^{71}$ According to the Supreme Court in Singh, an oral hearing will be necessary where there is a serious issue of credibility. ${ }^{72}$ Therefore, an applicant who could prove that credibility is at issue may argue that the Tribunal's limited ability to grant an in-person rather than a videoconference hearing violates his right to security of the person.

An applicant may also argue that having videoconference hearings in

71 See Suresh v. Canada Minister of Citizenship and Immigration [2002] 1 S.C.R. 3 at paras. 31 and 3637 , where the Court embraced the Baker framework for determining the degree and content of fairness. See also Charkaoui v. Canada (Citizenship and Immigration) 2007 SCC 7.

72 Singh v. Canada (Minister of Employment and Immigration) [1985] S.C.J. No. 11 at para 59 (QL). 
Northern Ontario while other Ontario residents have access to regular inperson hearings results in inequality before the law, as defined by s.15(1) of the Charter. In the wake of Hodge v. Canada Minister of Human Resources Development), ${ }^{73}$ the first step in a section 15(1) analysis must be the determination of the appropriate comparator group. ${ }^{74}$ The appropriate comparator group in turn must be identified in light of the legislation at issue. ${ }^{75}$ As noted above, the stated purpose of videoconference hearings is to regularly service remote centers and to allow disputes in Northern areas to be more promptly heard. The purpose of the legislation may thus be characterized as an attempt to facilitate hearings in remote areas so as to best approximate the readier tribunal hearing services available in urban centers. Where this attempt fails and in fact causes disadvantage to those whose hearings are held by videoconference, the appropriate comparison will be between remote residents, who are subject to videoconference hearings, and urban residents, who are not habitually subject to the same technology. ${ }^{76}$

Any comparison on the basis of residence will have to take account of the Supreme Court's decision in R. v. Turpin. In Turpin, an accused challenged the fact that a person accused of one of the offences listed in s.427 of the Criminal Code may opt under s.430 of the Code to be tried by judge alone in Alberta, but there was no such opportunity for those outside of Alberta. ${ }^{77}$ The Supreme Court held that the ability of an accused to be tried before a judge alone in one province and not another, violated his/her right to equality before the law. The opportunity to be tried by a judge alone instead of by a judge and a jury may have been to the advantage of the accused, but this advantage was only available to those accused in Alberta. ${ }^{78}$ The Court however went on to hold that this differentiation in treatment was not discriminatory. In examining the larger context, the court determined that there was no disadvantage that existed apart from and independent of the legal distinction. ${ }^{79}$ People accused of crimes listed in $\mathrm{s} .427$ of the Code resident in all provinces except Alberta could not be properly characterized as a discrete and insular minority. Moreover, there is no indication that those accused of offenses listed under 5.427 of the Code outside of Alberta suffer from any more stereotyping, disadvantage or vulnerability than those accused of these crimes in Alberta. ${ }^{80}$

Although the Court in Turpin dismissed the s.15 claim, the Court was careful to leave the door open for future findings of discrimination based on place of residence. Wilson J., writing for the court, emphasized that she "would not wish to suggest that a person's province of residence or place of trial could not in some circumstances be a personal characteristic of the

73 [2004] 3 S.C.R. 357.

74 Ibid. at para. 17.

75 Ibid. at para. 24.

76 For a broader discussion and critique of the Court's approach to comparator groups under s.15, see D. Gilbert and D. Majury, "Critical Comparisons: The Supreme Court of Canada Dooms Section 15” (2006) 24 Windsor Y.B.Access Just. 111.

77 [1989] 1 S.C.R. 1296 at para. 36.

78 Ibid. at para. $41-42$.

79 Ibid. at para. 45.

80 Ibid. at para. 47. 
individual or group capable of constituting discrimination." ${ }^{81}$ The differences between the North and South within Ontario may be the sort of regional disparity that could give rise to a successful claim under s.15 of the Charter.

To find that place of residence is an analogous ground under s.15 (1) of the Charter in this case, a claimant would have to show that residents of Northern Ontario as a group are a "discrete and insular minority" who come within the protection of s.15 (1), "in the context of the place of the group in the entire social, political and legal fabric of our society" ${ }^{82}$ It may be possible to make a viable argument that residents of Northern Ontario do qualify as such a discrete and insular minority and thus do constitute a group for whom residence is an analogous group under s.15(1).

Northern Ontario is plagued by a variety of problems, including "small local markets at a distance from larger markets, lack of economic diversification, an aging population and youth migration, government dependency and lack of investment potential." ${ }^{33}$ Northern Ontario's present condition is, in many ways, attributable to its history. Northern Ontario failed to develop an independent economic engine due to the cycles of expansion and contraction of its resource-based communities, dictated by provincial, national and global needs. ${ }^{84}$ Northern Ontario continues to be at a disadvantage, as indicated by present unemployment and education levels. Unemployment rates in Northern Ontario are consistently higher than in any other part of Ontario, ${ }^{85}$ with jobs in the "blue collar" industries being the largest single group of jobs in the regional economy. ${ }^{86}$ Northern Ontario has lower education levels than the rest of Ontario as well. Northern Ontario has $31 \%$ more people with less than a Grade 9 education than the rest of Ontario and $31.3 \%$ more people without a high school diploma. The most significant difference however, is the attainability of a university degree. In Ontario, $19.2 \%$ of people over the age of 20 have a university degree. In Northern Ontario, this percentage is only $10.7 \%$, for a difference of $44 \% .{ }^{87}$ The fact that Northern Ontario residents are routinely subject to videoconference hearings while other Ontario residents are not, in light of Northern Ontario's disadvantages, could lead to a finding of discrimination based on place of residence.

If a claimant does succeed in characterizing place of residence as an analogous ground and succeeds in identifying urban residence as the appropriate comparator group for a s.15 (1) claim, the claimant must still show that there has been discrimination in a substantive sense. The claimant must, in other words, demonstrate that videoconference hearings disadvantage residents of

81 Ibid. at para. 48.

82 Law Society of British Columbia $v$ Andrews, [1989] 1 S.C.R. 143 at para.5.

83 Maureen Woodrow, "Challenges to Sustainability in Northern Ontario" for the Environmental Commissioner of Ontario, May 10, 2002. online: Environmental Commissioner of Ontario $<$ http://www.eco.on.ca/english/publicat/csno.pdf $>$ at 1 .

84 Ibid.

85 See unemployment rates from 1996 to 2006 by region, online: Human Resources and Skills Development Canada <http://srv200.services.gc.ca/iiws/eiregions/uratesei.aspx>.

86 "Education Levels in Northern Ontario" 2001 Census Research Paper Series: Report \#9, online: Northern Ontario Training Boards < http://www.ntab.on.ca/files/census-reports.pdf $>$ at 5 .

87 Ibid. at $7-8$. 
Northern Ontario "in a manner which reflects the stereotypical application of presumed group or personal characteristics, or which otherwise has the effect of perpetuating or promoting the view that the individual is less capable or worthy of recognition or value as a human being or as a member of Canadian society, equally deserving of concern, respect, and consideration." "88 The Court in Law identified several contextual factors to aid in the determination of whether there has been discrimination in a substantive sense. These are: (1) pre-existing disadvantage, stereotyping, prejudice or vulnerability; (2) the correspondence, or lack thereof, between the ground on which the claim is based and the actual need, capacity, or circumstances of the claimant group; (3) the ameliorative purpose or effects of the impugned law upon a more disadvantaged person or group and (4) the nature and scope of the interest affected. ${ }^{89}$

If residence in Northern Ontario is accepted as an analogous ground under s.15 (1) for the purposes of this claim, it is likely that a court would also accept the assertion that residents of Northern Ontario experience disadvantage. The first contextual factor would thus be met. With respect to the correspondence factor, it must be noted that the purpose of videoconference hearings in the North is to facilitate regular hearings in remote centers and to allow disputes in Northern areas to be more promptly heard. Where videoconference hearings impede a person's ability to have his or her disputes heard and settled it is unlikely that a court will find correspondence between the provision of videoconference hearings and the needs, capacities and circumstance of the claimant group. There is no indication that videoconference hearings were implemented to ameliorate the circumstances of another disadvantaged group. This contextual factor would thus be of limited consequence. Finally, a court may find that the nature of the interest affected is significant. People who come before the Rental Housing Tribunal may be at risk of losing their homes.

Even if a court were to find no direct discrimination on the basis of place of residence, subjecting only those in the North to videoconference hearings may also give rise to a claim of adverse effect discrimination. $43 \%$ of Ontario's Aboriginal population lives in Northern Ontario, comprising over 10\% of Northern Ontario's population..$^{90}$ The population north of the $50^{\text {th }}$ parallel is almost entirely made up of Aboriginal communities. ${ }^{11}$ The disadvantages faced by the Northern Ontario population relative to the rest of Ontario are even more pronounced in Northern Ontario's Aboriginal population. Aboriginal labour force participation rates are lower than labour participation rates for the region as a whole, while Aboriginal unemployment rates are higher. ${ }^{92}$ Educational levels for Northern Ontario's Aboriginal communities are also lower than the average for both the region and the province. ${ }^{93}$ If it can be shown that Ontario's Aboriginal population is disproportionately affected by

88 Law $v$ Canada (Minister of Employment and Immigration), [1999] 1 S.C.R. 497 at para. 88.

89 Ibid.

90 "Northern Ontario Overview" online: Ministry of Northern Development and Mines <http:// www.mndm.gov.on.ca/mndm/nordev/redb/sector_profiles/northern_ontario_e.pdf> at p. 2.

91 "Aboriginal Communities in Northern Ontario" 2001 Census Research Paper Series: Report \#11, February 11, 2004. Muskoka online: Nipissing Parry Sound Local Training and Adjustment Board $<$ http://www.ltab20.on.ca/documents/census2001/reports/report11-eng.pdf $>$ at 4 . 
videoconference hearings, the ORHT's Northern videoconference hearings may be challenged on the grounds of adverse effect discrimination. A claimant would then have to demonstrate the existence of substantive discrimination, in a similar manner to the analysis outlined above, in order to prove adverse effect discrimination under s.15(1).

Leaving aside the challenges of sustaining an equality claim based on resources allocated to one region over another, there is a broader equality issue at the root of the videoconferencing which is the "equal benefit of the law." The language which introduces s. 15 sets out that every individual "is equal before and under the law and has the right to the equal protection and equal benefit of the law without discrimination..." A person who comes before a tribunal in Northern Ontario should not have less of a hearing than one who comes before that same tribunal in Ottawa or Toronto. Cost and geography require compromises but the question which merits attention is whether a particular compromise in a particular circumstance is justified.

If a section 15 challenge were accepted, the analysis would then turn to section 1 of the Charter, where the Supreme Court appears more willing than ever to defer to a government's preferences in terms of spending decisions. The high-water mark of this new deference is Newfoundland (Treasury Board) v. Nenfoundland and Labrador Association of Public and Private Employees (N.A.P.E.). ${ }^{94}$ In this case, Newfoundland decided to abandon a Pay Equity Settlement to its female civil servants on grounds of fiscal austerity. While accepting that this constituted a violation of the affected women's s.15 rights, the Court upheld the decision under s.1 as a reasonable limit on those rights. The Court required no empirical foundation for the provincial government's claim, nor any explanation for the government's prioritizing certain needs ahead of those at issue. While the Court acknowledged a government may be compelled to divert scarce resources to hospitals and schools, it could just as easily have concluded that the government deprived vulnerable workers of their due so as to pave more roads or spend tax dollars on the travel of cabinet ministers.

This approach stands in stark contrast to the Court's first articulation of principle in relation to s.1, which took place in circumstances more analogous to the concern over videoconferencing. In Singh, the Court found that the then refugee determination process denied claimants their s.7 rights because they had no opportunity for an oral hearing before the decision-maker in their case. With respect to s.1, Wilson J., on behalf of the three judges who decided the case under the Charter, held:

Certainly the guarantees of the Charter would be illusory if they could be ignored because it was administratively convenient to do so. No doubt considerable time and money can be saved by adopting administrative procedures which ignore the principles of fundamental justice but such an argument, in my view, misses the point of the exercise under s. 1. The principles of natural justice and procedural fairness which have long been espoused by our 
courts, and the constitutional entrenchment of the principles of fundamental justice in s. 7 , implicitly recognize that a balance of administrative convenience does not override the need to adhere to these principles. ${ }^{95}$

The Court more recently has suggested that it will defer more to governments respecting the infringement of social and economic rights than legal rights such as procedural fairness. Where such a principle could reconcile Singh and N.A.P.E., it is clear fairness will rarely be resource neutral.

In this section, we have canvassed the possible legal limits on administrative and budgetary decisions to opt for a particular kind of hearing. These limits are at best a smudged and dotted boundary - bright lines in this area are not to be found (and likely not to be desired either). A successful legal challenge to a tribunal's decision to employ videoconferencing is unlikely in general, though possible where particular circumstances suggest an unjust result tied to the absence of an in-person hearing. The Court has, to this point, shied away from the proposition that a government's spending on administrative justice is limited by constitutional or administrative law. Still, it is clear that public law and public administration are intertwined in the life of a tribunal and that, at some point, the rule of law and the budgetary choices of government converge.

\section{CONCLUSION}

While creative lawyers would have arguable positions on the existing constitutional and administrative law standards whereby compromising fairness through reliance on videoconferencing breaches the tribunal's legal duties, there is a clear sense of reticence on the part of courts to head down this road. We conclude that courts have the mandate (and, consequently, the obligation) to review the Government's allocation of resources to the administration of justice (including adjudicative administrative settings). This flows not just from the specific common law and Charter procedural fairness obligations set out in the analysis above but also from the rule of law and its concern that basic minimum entitlements to access be respected.

Just as courts could not permit a government to shut down courthouses or restrict access to courthouses with impunity, so too courts cannot allow government funding to adjudicative bodies to be allocated according to policy preference alone. Administrative tribunals, such as the former ORHT and the present Landlord and Tenant Tribunal, are creatures of statute, and it is open in those statutes to provide for oral hearings, electronic hearings, written hearings or no hearings at all, however, where hearings are contemplated, fairness requires a certain reasonable investment of resources to support such adjudication.

To say that the allocation of resources to administrative tribunals is a relevant matter for a court to consider in the context of a judicial review of a tribunal's decisions is not to say it is appropriate or desirable for courts to micromanage the affairs of tribunals or that it is illegitimate for government to cut budgets where it is deemed necessary. It is simply a matter of recognizing 
the obvious; that is, that respecting fairness will in almost every case require resources. It is simply not tenable for courts to assert that they have carriage over every aspect of procedural fairness except what in many cases will be the determinative one. Thus, in Singh, the Court did not dictate how much the federal government had to spend on refugee determination proceedings, but the Court did direct that an oral hearing was required in circumstances where none was then provided. The result was, of course, a significant new cost for the Government. Such resource choices remain for government. It is further the government's policy of providing a refugee process or dispute resolution for landlords and tenants that also remains a choice. Once government makes choices which establish adjudicative settings, the court may defensibly impose constraints on how those settings are structured and funded. In light of this, it is surprising how rarely courts have considered the resource allocation for adjudicative bodies as part of its procedural review (whether under administrative law or Charter principles). While a challenge on this basis has yet to be brought in the context of the ORHT, we would suggest that this is an appropriate setting to test a broader approach to the procedural obligations of tribunals in relation to videoconferencing.

While such a challenge could represent a modest advance in the jurisprudence, and a salutary recognition of the concrete implications of the rule of law for adjudicative settings, it may have widespread and more important benefits for how administrative bodies are designed and constituted. These legal norms regarding the sufficiency of budgetary and administrative structures for a particular adjudicative task are best integrated when a tribunal is being designed, not when its decisions are being challenged. As courts clarify such obligations, government and legislative framers of these tribunals can ensure they comply with such norms at the outset.

Where governments wish or need to make strategic decisions based on scarce resources, these legal norms may provide guidance as to how such decisions will enhance the capacities and credibility of tribunals rather than jeopardize their ability to deliver administrative justice. Ultimately, however, it may be that the cost of administrative justice is more than what a particular government can afford or wishes to spend - in such cases, the rule of law considerations must prevail. While some constitutional concepts such as judicial independence may apply only to courts and not to administrative tribunals, other concepts follow the rights at issue and the impact on those affected rather than on the body which has been delegated the power to decide. The rule of law, surely, is one such constitutional aspect. The rights of tenants facing the loss of their home, is an example of where the rule of law must apply, whether government decides to delegate dispute resolution to a court or to a tribunal. The rule of law, moreover, is not self-executing. While it may fall to the courts to articulate the contours of the rule of law, it falls to the executive to make the rule of law real in its day-to-day decision-making environments. We can think of no question for administrative law of greater significance than how the executive discharges this obligation. 